\title{
Agro-ecological zones delineation based for agricultural development in Sinai Peninsula using geo-informatics techniques
}

\author{
S. M. Abou-Shleel 1, ${ }^{*}$, M. E. Jalhoum ${ }^{2}$, and A. Belal ${ }^{2}$
}

${ }^{1}$ Environment and Bio-Agriculture Department, Faculty of Agriculture, Al-Azhar University, Nasr city, Cairo, Egypt

${ }^{2}$ National Authority for Remote Sensing and Space Sciences (NARSS), Ministry of Higher Education, Cairo, Egypt

*Corresponding author E-mail: s_masoud_2006@azhar.edu.eg (S. Abou-Shleel).

\begin{abstract}
Agricultural development faces many obstacles, such as soil drought, climate change, and human activities, but the main challenge facing Egypt today is the need to develop and better manage natural resources to meet the growing needs of the country. This study aims to map Sinai agro-ecological zones to find out the most suitable environmental condition to growth, development and productivity of agricultural corps using geo-informatics techniques. Nine ground agro-meteorological stations distributed over the study area were used to collect the climatic data from 1986 to 2015. Also, the physiochemical properties of soil were determined. The land capability was carried out using ALES-arid. Model builder with integration of GIS based on an approach using DEM, landsat8 satellite data, soil analysis and climatic data were utilized to evaluate the agro-ecological zones for agricultural production. The results indicated that land capability was classified as $2.2 \%$ belong to $\mathrm{C} 3$ (fair), $8.5 \%$ belong to $\mathrm{C} 4$ (poor), $11.9 \%$ belong to C5 (very poor) and $4.4 \%$ fits in C6 (non-agriculture). In addition, the Model builder results showed that the study area comprise five zones; i.e. zone (I) high suitable areas (4.1\%), zone (II) suitable area (0.1\%), zone (III) moderately suitable (15.7\%), zone (IV) marginally suitable $(7.2 \%)$ and zone (V) non-suitable area $(9.1 \%)$. It could be concluded that, zones I, II, and III were considered the best suitable zones for agricultural development in Sinai Peninsula.
\end{abstract}

Keywords: Agro-ecological zones; geo-informatics; geomorphology; land capability; Sinai Peninsula.

\section{INTRODUCTION}

Agriculture in Egypt has been a landmark in the national economy since ancient history. This was aided by the fact that Egyptian soil consists of alluvial soils in the delta and valley, limestone soils along the coast line, and eastern and western deserts, as well as the Sinai Peninsula., Hamdi and Abdelhafez (2001). Sinai in particular and the eastern desert in general have a low population density compared with the Nile Valley and the Delta. Therefore, it is considered as an important area for the establishment of new urban societies, due to its strategic location in addition to its richness in natural resources such as minerals and arable soils. The Sinai desert covers about $6 \%$ of the total land area of Egypt and its floristic importance stems from its unique position at the junction of Asia and Africa. The natural conditions and geographical position of Sinai Peninsula make it a very distinctive region, (Gad and Shalaby, 2010).

Nowadays, the lack of arable land is one of the most important challenges facing developing countries, the most important of which is Egypt, and this problem is mainly exacerbated by the number of variables, for example the increasing rate of population growth, low soil fertility and climate changes. It is known that $95 \%$ of the total area of Egypt is considered a desert, Mahmoud et al. (2019). Also, the biggest challenge in Egypt is the ratio between land resources and population, AbdelHamid et al. (2010). Sustainable agricultural development requires regular planning and an appropriate agricultural policy for land use, regardless of institutional initiatives and national policy programs. It has some limitations such as high salinity, geomorphological characteristics (i.e. very high elevation, a high degree of slope, less soil depth and the presence of bare rocks) Jalhoum (2019).

Agro-ecological zoning (AEZ) is one of the most important foundations and approaches for agricultural development, as the survival or failure of a particular use of land or agricultural system depends heavily on accurate assessment of agricultural and climate resources, (Patel, 2003 and Suriadikusumah, 2014). On the other hand, the application of AEZ is limited by lack of geospatial data in mountainous areas, (Ismail, 2012).

Modern tools and technologies, such as satellite data and GIS, provide an effective tool for managing natural resources as they play a major role in sustainable agricultural 
development. A comparison has been made between the historic and future agro-ecological zone to assess the impact of climate change on farmland, Annmaria et al. (2010). In this context, MicroLEIS was used as a decision support system (DSS) to identify the main factors affecting soil productivity and suitability for agriculture, El Bastawesy et al. (2008), Salem et al., (2008). Also, Belal et al., (2015) used GISSpatial Multi-Criteria Evaluation (SMCE) model for evaluating land capability and suitability in Wadi Al Assiuti, Egypt. Moreover, Hassan, (2017) used Micro LEIS-Cervatana module for capability assessment of some areas in middle EGYPT, and who found that $8.5 \%$ of land was good, $24.7 \%$ was moderate capability, and $9.1 \%$ of total area was marginal or null.

The current study is considered one of the continuous trails to evaluate the desert areas in terms of agriculture in order to explore the areas of high production capacity in Sinai Peninsula. The study aims to evaluate Sinai agro-ecological zones in order to find out the best suitable environmental conditions for growth, development and productivity of agricultural crops using geo-informatics techniques.

\section{MATERIALS AND METHODS}

\section{Study area}

The Sinai Peninsula is located in the northeastern portion of Egypt and is bounded by longitudes $32^{\circ} 20^{\prime} \& 34^{\circ} 52^{\prime} \mathrm{E}$ and latitudes $27^{\circ} 45^{\prime} \& 31^{\circ} 10^{\prime} \mathrm{N}$. It occupies an area of about $61,000 \mathrm{~km}^{2}$ or about $6 \%$ of Egypt's total area. The Peninsula has a triangular shape; its apex is to the south at Ras Mohammed (south of latitude $28^{\circ}$ ), whereas its base is to the north extending along the Mediterranean coast between Port Said and Rafah for about 210.0 $\mathrm{km}$. Sinai is bounded in the eastern side by the Gulf of Aqaba and the international border and in the west by the Gulf of Suez and the Suez Canal, as shown in Fig. (1).

\section{Data collection}

Image processing software ENVI (5.1) was used for image analysis. Landsat- 8 image acquired on 2015 was employed in this study. The remotely sensed data and soil maps were geometrically projected to UTM Zone $37 \mathrm{~N}$ coordinate system using WGS 84 datum.

The nine ground agro-meteorological stations were chosen to collect the climate data, whereas it was distributed on all Sinai according to geographic coordinate system as shown in Fig. (2). the annually average climate factors (Solara radiation, minimum and maximum temperature, wind speed, relative humidity, and precipitation) during the period of 1986 to 2015.

A map of digital elevation model has been produced and implemented using the ArcGIS 10.2 , this map shows that the study area varies from one part to another as the sea level changing from -10.0 to $2618.0 \mathrm{~m}$ above sea level as shown in Fig. (3).

\section{Field work and_digital soil mapping}

Geomorphological units were recognized and delineated by analyzing the main landscape that was extracted from visual interpretation of satellite image draped over DEM to get the natural stereo terrain features with the aid of the different topographic maps and field work survey. Forty-seven soil profiles were dig and described to recognize the different landform units, the collected soil samples were air dried, sieved through $2 \mathrm{~mm}$ sieve. Then, the physical and chemical properties were determined according to (USDA, 2004). Detailed morphological description was recorded for each of the studied soil profiles, on the basis outlined by (Soil Survey Staff, 2017); the soil taxonomy was used to classify soil of the study area to the sub great group level according to USDA (2014).

\section{Land capability}

Land capability classification was applied by using ALES-arid model (Ismail et al., 2005) based on the soil physical and chemical characteristics. The capability evaluation includes six orders as the following: Excellent $(\mathrm{C} 1)$, good (C2), fair (C3), poor (C4), very poor (C5) and non-Agriculture (C6).

\section{Agro-ecological zones modeling}

The climatic data and soil profiles were mapped using Inverse Distance Weighting (IDW) interpolation method in ArcGIS 10.4. Once the input of model was determined, then the agro-ecological zone model which consists of several steps to obtained the agro-ecological zones maps as shown in Fig. (4).The input dataset can be assigned a percentage influence, based on its importance on soil productivity as suggested; the total influence for all datasets must equal 100 percent. The cell values of each input dataset are multiplied by their influence percentages (weight). Finally, the resulting cell values are added together to create the final output dataset of this model which locate an area more suitable for agricultural development. 


\section{RESULTS AND DISCUSSION}

\section{Assessment of climatic factors in Sinai Peninsula}

The available meteorological data (Fig. 5-7) represents the climatic data of Sinai Peninsula. Climatic information is based on monthly averages for the 30-year period 1986-2015 illustrates the following; monthly temperature means values indicate that the maximum and minimum values have similar trend during the year. The Annual average temperature was 22.0-27.4 ${ }^{\circ} \mathrm{C}$ with maximum and minimum mean values of $24.1-29.71^{\circ} \mathrm{C}$ and $19.8-25.1^{\circ} \mathrm{C}$, respectively. The highest temperature value of $37.5^{\circ} \mathrm{C}$ was recorded in July and August, while the lowest one $7.5^{\circ} \mathrm{C}$ was found in January (Fig. 5). The obtained results indicated that the climate in the Sinai Peninsula is characterized by a hot climate, or very hot with a high temperature. It is characteristic of the Mediterranean climate in the northernmost of Sinai, to be close to the desert and semi-desert in the south. These results are in agreement with those obtained by El Afandi et al., (2013) who reported that the mean daily maximum temperature of Sinai Peninsula is $28.0-37.0^{\circ} \mathrm{C}$ in the north, $31.0-42.0^{\circ} \mathrm{C}$ near the south coast, and 35.0-41.0 ${ }^{\circ} \mathrm{C}$ inland during the period June to October. Also, El Asrag et al., (2003) found that the average temperatures range from 18.0$31.0^{\circ} \mathrm{C}$ in summer and from $7.0-21.0^{\circ} \mathrm{C}$ in winter.

Concerning with radiation, the results presented in Fig. 6 indicated that the amount of radiation in Sinai was increased from the northeast towards the southwest. The greatest amount of the annual radiation was found at the coastal areas over the Gulfs of Aqaba and Suez (Sharm Elshikh station) in the southern region. The annual radiation average was about $21.8-22.2 \mathrm{MJ} / \mathrm{m}^{2} /$ day along the red coast. It was decreased into the north, where the annual radiation in the northern region was significantly less than the southern one, where it reached 19.8-20.2 $\mathrm{MJ} / \mathrm{m}^{2} /$ day along the Mediterranean coast (Al-Arish station).

Precipitation was very variable, the amount of rainfall in Sinai was decreased from the northeast towards the southwest. The maximum amount of the annual precipitation was found at Al-Arish station in the northeast. The annual rainfall average was about 148.6$177.1 \mathrm{~mm}$ along the Mediterranean coast. It was decreased into the south, where the annual rainfall in the southern region was significantly less than the northern one, where it reached $22.5-52.8 \mathrm{~mm}$ in the coastal areas over the Gulfs of Aqaba and Suez (Sharm Elshikh station) (see Fig. 6). The precipitation is ranging from medium to heavy at some high terrain areas in winter and autumn seasons. The rainfall is completely nonsexist in summer season. These results are in a harmony with those obtained by El Afandi et al., (2013). In addition, Al-Gamal and Sadek (2015) found that the mean annual rainfall for Sinai is about $40.0 \mathrm{~mm}$. This mean that Sinai Peninsula has a very arid desert climate (annual precipitation less than 300.0 $\mathrm{mm}$ ) (El Asrag et al., 2003) with exception of a narrow zone of few $\mathrm{km}$ along the coast which has a more moderate similar to other areas in the eastern Mediterranean basin.

The data illustrated in Fig. 7 showed that the general trends of wind and humidity in Sinai Peninsula. Records of wind velocity ranged from $3.44 .3 \mathrm{~m} / \mathrm{s}$. The maximum monthly mean was recorded in January, while the minimum one was recorded in August. North and north western dry winds prevail most of the year on the northern part of the region, while on the southern part south eastern rain fed winds prevail in the period from July and September. Winds are usually from the west, parallel to the coast. Finally, the amount of relative humidity in Sinai was decreased from the northeast towards the southwest. The greatest amount of the annual humidity was found at Al-Arish station in the northeast.

The annual humidity average was about 60.8-65.4\% along the Mediterranean coast. It decreased in the uplands to the south, where the annual humidity in the southern region was significantly less than the northern one, where it reached $37.3-41.7 \%$ in the coastal areas over the Gulfs of Aqaba and Suez (Sharm Elshikh Station). The lowest value was recorded in July, while the most humid months were January and February. In general, low humidity values are inversely related to temperature changes indicating the predominance of dry and hot climate, and it was the same direction of precipitation.

\section{Assessment of evapotranspiration (ETo) in Sinai Peninsula}

The data illustrated in Fig. (8) indicated that the annual mean evapotranspiration $\left(E_{0}\right)$ in Sinai Peninsula, whereas it was affected by air temperature, air humidity and wind speed. The annual mean of evaporation ranges from 6.5 to $8.0 \mathrm{~mm} /$ day. The highest values $(8.0 \mathrm{~mm} /$ day $)$ are recorded in south Sinai areas, while the lowest value $(6.5 \mathrm{~mm} /$ day $)$ was recorded in North Sinai areas. This means that the crop requirements from water irrigation must be 
considered through the planning to the agricultural development in south Sinai especially.

\section{Geomorphology units and soil taxonomy of Sinai Peninsula}

The main geomorphological units and soil taxonomy and its main characteristics are described in the following (Table 1 and Fig. 9 10).

\section{Alluvial Fans}

The fan soils occupy large area of wadi and take the same level of upper terraces in this wadi. Its surface is slightly undulating, barren from natural vegetation, characterized by narrow vertical and lateral cracks. Theses soils are mainly formed of calcareous material mostly of alluvial origin. It was covering about 194713.5 acres of the total area. The depth of soils around $150 \mathrm{~cm}$, the texture is coarse to fine sand. The calcium carbonate content present in the same content $(40 \%)$ in all layers of the soil profiles. Gypsum content is low in these soils, it ranges between 0.18 to $0.3 \%$ in the successive layers of soil profiles. Organic matter content is very low (less than $1 \%$ ). The soil salinity values reveal that, the electrical conductivity (ECe) ranges between 0.5 to $2.5 \mathrm{dS} / \mathrm{m}$. The $\mathrm{pH}$ values ranged between (7.6 to 8.2 ) in the successive layers of the studied profiles. CEC ranges between $3.6-6.7 \mathrm{meq} / 100 \mathrm{~g}$ soils in the different layers of the soil profiles. The soils of this unit are classified as Vertic Torriorthents.

\section{Coastal plains}

Low lying areas parallel to the beach affected by the sea and it which occupies the northern part of this area. It was covering about 623881.2 acres of the total area. Soil texture sand to loamy sand in the successive profile layers. The calcium carbonate content ranges between $0.45-1.34 \%$ in the different layers of the soil profiles. Gypsum content is low, it ranges between $0.18-0.25 \%$ in the successive layers of soil profiles. Organic matter content is very low and it ranges between $0.03-0.04 \%$. The soil salinity values reveal that, the electrical conductivity (ECe) ranges between $0.89-0.5$ $\mathrm{dS} / \mathrm{m}$. The $\mathrm{pH}$ values ranged between $8.15-8.3$ in the successive layers. CEC ranges between $5.75-6.45 \mathrm{meq} / 100 \mathrm{~g}$ soils in the different layers of the soil profiles. These soils are classified as Typic Torrifluvents.

\section{Decantation basins}

Low land areas, higher than depressions bounded by higher lands. It was covering about 24621.8 acres of the total area. Soil texture is loamy and loamy sand in the successive profile layers. The calcium carbonate content ranges between $23-56 \%$ in the different layers of the soil profiles. Gypsum content is low, it ranges between $0.18-0.25 \%$ in the successive layers of soil profiles. Organic matter content is very low content less than 0.1 . The electrical conductivity (ECe) less than $5 \mathrm{dS} / \mathrm{m}$. The $\mathrm{pH}$ values ranged between (7.1 to 8.0) in the successive layers of the soil profiles. CEC ranges between 5.75 - 6.45 meq/100 $\mathrm{g}$ soils in the different layers of the studied soil profiles. The soils of this unit are classified as Typic Calciorthids.

\section{Delta}

Large deposit located at the mouth of a stream. It is alluvial sediment. Deltas in the study area are consisting of sandy and silty deposits formed from water erosion actions. Some natural vegetation is spreading over the delta's surfaces and a thin clayey mantle on the surface formed in some low land areas. It was covering about 44928.8 acres of the total area. The soils are loose and deep; sandy texture of and $\mathrm{CaCO}_{3}$ dominate in Oolitic form. The calcium carbonate content ranges between 25$65 \%$ and increases to over $90 \%$ in the Oolitic dunes. Gypsum content is low, it ranges between 0.18 to $0.25 \%$ in the successive layers of soil profiles. Organic matter content is very low and it ranges between 0.03 to $0.04 \%$. The electrical conductivity (ECe) ranges between 0.89 to $1.5 \mathrm{dS} / \mathrm{m}$. The $\mathrm{pH}$ values ranged from 7.3 to 8.4. CEC ranges between 2.0 to $7.45 \mathrm{meq} / 100$ $\mathrm{g}$ soils in the different layers of the soil profiles. The soils of this unit are classified as Oolitic Torripsamments.

\section{Outwash plain}

A flat or gently sloping surface of sediments deposited by melt water streams. It found at the foot of the hilly to mountainous land and composed gravel but for the greater part sandy. Soil texture is sand and the calcium carbonate content less than $10.13 \%$ in the different layers of the soil profiles. Gypsum content is low, its content less than $0.41 \%$ in the successive layers of soil profiles. Organic matter content is low content less than 0.22. The electrical conductivity (ECe) less than $0.96 \mathrm{dS} / \mathrm{m}$. The $\mathrm{pH}$ values content 8.1 in the successive layers of the soil profiles. CEC content $6.75 \mathrm{meq} / 100 \mathrm{~g}$ soil in the different layers of the studied soil profiles. The soils of this unit are classified as Typic Torripsamments.

\section{Wadis}

A linear depression that slopes down to a stream, or the sea. It was formed by water 
action through flashfloods. They are one of the predominant geomorphic subunits in the plain; they are formed as a result of water action through the "Pluvial" period when the annual rainfall and surface runoff were active. It was covering about 839719.0 acres of the total area, the soil texture is sand, loamy sand, sand loamy and clay loam in the successive profile layers. The calcium carbonate content ranges between 0.55 to $26.03 \%$. Gypsum content is very low, it ranges between 0.33 to $0.52 \%$ in the successive layers of soil profiles. Organic matter content is low and ranges between 0.0 .2 to $0.2 \%$. The electrical conductivity (ECe) ranges between 1.13 to $2.2 \mathrm{dS} / \mathrm{m}$. The $\mathrm{pH}$ values ranged between (7.85 to 8.3) in the successive layers of the soil profiles. CEC ranges between 4.45 - 17.5 meq/100 $\mathrm{g}$ soils in the different layers of the studied soil profiles. The soils of this unit are classified as Typic Torripsamments and Typic Calciorthids.

\section{Foot-slopes}

Inclined surfaces represented the foot of the mountains. Surfaces of these units tend to surrounding to roll peneplains or sand sheets. It was covering about 672296.9 acres of the total area. This unit was characterized by shallow soil depth; the soil texture varies sand in the successive profile layers. The calcium carbonate content more than $9.5 \%$ in the different layers of the soil profiles. Organic matter content is low content less than $0.05 \%$. The electrical conductivity (ECe) more than $5.0 \mathrm{dS} / \mathrm{m}$. The $\mathrm{pH}$ values content 7.5 in the successive layers of the soil profiles. CEC is content $4.5 \mathrm{meq} / 100 \mathrm{~g}$ soil in the different layers of the studied soil profiles. It is classified as Lithic Calcic Gypsiorthids.

\section{River Terrace}

These landforms ideally represent the ultimate stage in the cycle of desert erosion. They occur when foot-slopes finally cut through plateau ranges and intersect each other leaving a few isolated residual knobs of bedrocks. River terraces are categorized as high river terrace, moderate river terraces and low river terrace according to their elevations. They cover about 215357.2 acres of the total area. This unit was characterized by deep soil where the depth reached to $165 \mathrm{~cm}$, the soil texture is sand in the successive profile layers. The calcium carbonate content ranges between 0.3 to $8.83 \%$ in the different layers of the soil profiles. Gypsum content is low too high, it ranges between 0.1 to $21 \%$ in the successive layers of soil profiles. Organic matter content is very low and ranges between 0.02 to $0.08 \%$. The electrical conductivity (ECe) ranges between 0.4 to 1.25 $\mathrm{dS} / \mathrm{m}$. The $\mathrm{pH}$ values ranged between 7.9 to 8.8 in the successive layers of the soil profiles. The cation exchange capacity ranges between 4.45 to $10.05 \mathrm{meq} / 100 \mathrm{~g}$ soil in the different layers of the studied soil profiles. The soils of this unit are classified as Typic Torripsamments.

\section{Sandy sheets}

This unit is formed by wind action. This unit is subdivided into high sand sheet, moderate sand sheet and low sand sheet sand sheets are consisting of loose sands. They are nearly flat to undulating with some natural vegetation. It was covering about 260787.6 acres of the total area. The soil depth was ranged between (130.0 $-150.0 \mathrm{~cm})$; soil texture is sand to in the successive profile layers. The calcium carbonate content is low to moderate and it ranges between 0.55 to $7.8 \%$ in the different layers of the representative profiles. Gypsum content is very low, it ranges between 0.2 to $0.52 \%$ in the successive layers of soil profiles. Organic matter content is low and ranges between 0.01 to $0.08 \%$. The electrical conductivity (ECe) ranges between 0.63 to $2.2 \mathrm{dS} / \mathrm{m}$. The $\mathrm{pH}$ values ranged between (7.85 to 8.3) in the successive layers of the soil profiles. CEC ranged between 4.45-11.15 meq/100 $\mathrm{g}$ soils in the different layers of the studied soil profiles. The soils of this unit are classified as Typic Torripsamments.

\section{Sabkhas}

These unite is covering about 196429.5 acres of the total area. These soils have flat to almost flat surfaces, these soils are adjacent to the El Bardawil Lake as well as northern part of ElTina plain. The soil texture was clay, sand to sand clay loamy sand in the successive profile layers. The soil depth ranges reached to $80.0 \mathrm{~cm}$; the calcium carbonate content ranges between 1.51 to $2.85 \%$ in the different layers of the soil profiles. Gypsum content is slight to moderate, it ranges between 5.05 to $7.8 \%$ in the successive layers. Organic matter content is low and ranges between 0.55 to1.15 percent. The electrical conductivity (ECe) ranges between 109.4 to $121.4 \mathrm{dS} / \mathrm{m}$. The $\mathrm{pH}$ values ranged between (7.19 to 7.69) in the successive layers of the soil profiles. CEC ranges between 20.45 to $42.4 \mathrm{meq} / 100 \mathrm{~g}$ soil in the different layers of the soil profiles. The soils of this unit are classified as Typic Hydraquents.

\section{Sandy plains}

These plains are flat to gently undulating broad floors that are covered by sand. Sand plain is formed by wind action and they are consisting of loose sands with some natural 
vegetation. It was covering about 631803.0 acres of the total area, and the soil of sandy plain was characterized by deep soil profile and the texture is sand in the successive profile layers. The calcium carbonate content ranges between 5.38 to $8.82 \%$ in the different layers of the soil profiles. Gypsum content is low, it ranges between 0.09 to $0.17 \%$ in the successive layers of soil profiles. Organic matter content is very low and ranges between 0.03 to $0.07 \%$. The electrical conductivity (ECe) ranges between 0.3 to $0.46 \mathrm{dS} / \mathrm{m}$. The $\mathrm{pH}$ values ranged between (7.93 to 8.47). CEC ranged between 4.55-8.0 $\mathrm{meq} / 100 \mathrm{~g}$ soils in the different layers of the soil profiles. It was classified as Typic Torripsamments.

\section{Peniplains}

This unit is low relief and it was formed from several pediments. It was covering about 422938.9 acres of the total area.

\section{Sand dunes}

These have an oblique direction according to the prevailing wind direction. The local relief differences have an effect on their directions. It was covering about 1113614.3 acres of the total area.

\section{Rock land}

These units are occupying great of the study area as that located in the southern part. They are composed of igneous and metamorphic rocks. Mountains could be categorized to high mountains, middle mountains and low mountains. Mountains, Hills and Rock out crops are covering areas of 8654707.2 acres of the total area.

\section{Assessment of land capability in Sinai Peninsula}

Based on the soil physical and chemical characteristics, soil capability indices were calculated for soils in the studied area using ASLE-arid system the studied area was classified into four capability classes as shown in Table (2) and Fig. (11).

\section{Fair capability (C3)}

Soils of this class have more limitations factors that need moderate intensive management or moderately restrict the range of crops, or both. Soils in this class have fair soil index between 44.4 to $59.5 \%$. This class is covering about 300890.4 acres of the total area.

\section{Poor capability (C4)}

Soils in this class have several limitation factors that exclude the use of the land that need special management practices or moderately restrict the range of crops, or both. The limitations factors such as salinity, soil depth and content of clay is low because it has low soil index (26.4 to $39.3 \%$ ). These lands require good and proper management. These soil units will be improved to be fair or good. They are moderately high in productivity for fair range of crops. This class is covering about 1178509.4 acres of the total area.

\section{Very poor capability (C5)}

Soils in this class have more limitation factors this C5 severe that excludes the use of the land, or with one or more severe limitation that need special management practices or severely restrict the range of crops, or both. These soil units have some limitations such as salinity, soil depth, content of clay is low and carbons and gypsum contents because it has low soil index (16.9\%). These lands require good and proper management. These soil units will be improved to be fair or good. They are moderately high in productivity for fair range of crops. This class is covering about 1663500.4 acres of the total area.

\section{Non-agriculture capability (C6)}

The limitation factors of C6 such as texture, highly salinity, high contents of $\mathrm{CaCO}_{3}$, high contents of gypsum and very shallow soil depth like sabkhas and foot-slopes units. It has low soil index ranging from (3.6 to $4.8 \%$ ). This class is covering about 610710.6 acres of the total area.

The data refer that the highly capable soils (Class 3) in the study area are found associated with same wadis. While soil salinity and soil texture, they are limiting factors in class 4 and 5 in the study area. They exhibit mainly the northern and western parts of Sinai Peninsula. While, the low capable soils (class 6) in the study area associated with the soils of Lithic Calcic Gypsiorthids, Typic Hydraquents and found mainly close to coastal area (sabkhas) and the depressions margins (foot-slopes). These outcomes were steady with earlier investigations of Ghabour (1998) who reported that the land of Northern Sinai is placed in four capability classes from III to VI. Most of the soils formed in the wide wadis belong to class III, as they have moderate limitations. Vast area is classified into capability class IV including the soils of various landforms such as coastal sand dunes, sand flats, plains, delta plain, alluvial fans, playa, foot slope, evaporates and dry sabkha. While class $\mathrm{V}$ includes the sand dunes and wet sabkha land forms, steep upland, hills, 
plateau, denuded hills and swamps are placed in class VI.

\section{Agro-ecological zones delineation in Sinai Peninsula}

Agro-ecological zones in this study are treat to be land entities that are uniform in terms of land form, soil features and climatic for planning objectives. They are unique where used the specific combinations about landforms, soils and climate, which has been considered as input to agro-ecological zones mapping. The soils differ in their properties according to mode of geomorphological position. The spatial and non-spatial data for the soils were converted into digital resource databases for AEZ. Based on the results of overlay maps of agro-climate and agro edaphic, there were obtained five (5) agro-ecological zones AEZ (Table 3 and Fig.12). The model was applied to the agro-ecological zones layer, as follows:

\section{Zone (I)}

They represent highly suitable areas. It has very good and suitability for most crops. Where, it has very slight restrictions that restrict its use and that require proper crop production management. This zone is characterized by deep soil and high clay content. Their contents from salinity, carbonate and gypsum are very low with slopes $<1 \%$. It appears in delta and some wadis units. This zone is covering about 565999.5 acres of the total area.

\section{Zone (II)}

They represent suitable areas. It has good and suitability for most crops. It has one slight limitation that restricts its use for the production of common agricultural crops. This zone was characterized by deep to moderately deep, the texture is sandy loam to loamy. It has moderately affected with alkaline and moderate of salinity, where the electric conductivity values range between $2-4 \mathrm{dS} / \mathrm{m}$. Their contents from carbonate ranges between $2-4 \%$ and gypsum is low ranging between 0.5 - $1.5 \%$ with slopes are $2 \%$. This zone is covering about 8080.7 acres of the total area.

\section{Zone (III)}

They represent moderately suitable areas for some crops. It has one or more severe limitation that excludes the use of the land that requires special management practices or severely restricts the range of crops such as salinity, where the electric conductivity values range between $4-6 \mathrm{dS} / \mathrm{m}$. and content of clay is low. This zone is characterized by moderately deep and it have moderately affected with alkaline. Their contents from carbonate and gypsum are moderately with slopes $<10 \%$. This zone is covering about 2184353 acres of the total area.

\section{Zone (IV)}

They represent marginally suitable areas. It has one or more severe limitation that excludes the use of the land, or with one or more severe limitation that require special management practices or severely restrict the range of crops, or both. It has some limitations such as salinity, where the electric conductivity values range between $6-8 \mathrm{dS} / \mathrm{m}$., content of clay is low and carbonate and gypsum contents are relatively high, where the carbonate contents up to $10 \%$ and gypsum values ranges between $3-5 \%$. This zone needs good management practices to improve its current situation. So, the current capability of this zone can be changed to be good with moderately intensive management practices. This zone is covering about 997885.1 acres of the total area.

\section{Zone (V)}

is non-suitable areas, it has severe or very severe limitations that cannot be corrected such as texture is sandy to sandy loam, highly salinity values $>30 \mathrm{dS} / \mathrm{m}$, high contents of carbonate up to $>15 \%$, gypsum values range between $5-11 \%$, and shallow soil profile is $50-$ $70 \mathrm{~cm}$. So, the current capability of this zone cannot be changed to be good. This zone appears in sabkhas, pediment and some terraces units. This zone is covering about 1263769.7 acres of the total area.

\section{CONCLUSION}

This study was primarily focused on the identification of the suitable agriculture for agro-ecological zones in Sinai Peninsula. However, the problems of the low production caused by one or more severe limitation that excludes the use of the land, or that require special management or severely restrict the range of crops. Therefore, the agro-ecological zone can be considered a set of applications that lead to assessment of lands and potential productivity in terms of climate, soil and landforms. It could be concluded from the obtained results that the zones I, II and III were considered the best suitable zones for agricultural development in Sinai Peninsula, it covering about 574080.2 acres of the total area. So that natural resources in Sinai would have a promising future for agricultural expansion projects if both suitable reclamation methods and appropriate management practices were applied. 


\section{REFERENCES}

Abdel-Hamid, M.A., Ismail, M., Nasr, Y.A., Kotb, Y., 2010. Assessment of soils of Wadi El-Natrun Area, Egypt using remote sensing and GIS techniques. J. Am. Sci., 10 (6), 195-206.

Al-Gamal, S.A., Sadek M., 2015. An assessment of water resources in Sinai Peninsula, using conventional and isotopic techniques, Egypt. Int. J. Hydrol. Sci. Technol., 5 (3), 241-257.

Annmaria, C., Daniela, D.B., Giacoma, G., Donato, S.F., 2010. Characterization, delineation and visualization of agro-ecozones using multivariate geographical clustering. Ital. J. Agron., (5), 121-132.

Belal, A.A., Mohamed, E.S., Abu-hashim, M.S.D., 2015. Land evaluation based on GIS-spatial multi-criteri evaluation (SMCE) for agricultural development in dry Wadi, eastern desert, Egypt. Int. J. Soil Sci., 10, 100-116.

El Afandi, G., Morsy, M., El Hussieny, F. 2013. Heavy rainfall simulation over Sinai Peninsula using the weather research and forecasting model. Int. J. Atmos. Sci., 2013, 241050.

El Asrag, A.M., Al-Gamal, S.A., Ahmed, D.M. 2003. Spatial and temporal variation of rainwater stable isotopes in Egypt and the East Mediterranean. Theor. Appl. Climatol., 74 (3), 191-202.

El Bastawesy, M.A., Ali, R.R., Nasr, A.H., 2008. The use of remote sensing and GIS for catchments delineation in Northwestern coast of Egypt: An Assessment of Water Resources and Soil Potential. Egypt. J. Remote Sensing Space Sci., 11, 3-16.

Gad, A., Shalaby, A., 2010. Assessment and mapping of desertification sensitivity using remote sensing and GIS case study: Inland Sinai and Eastern Desert Wadies. US-Egypt Workshop on Space Technology and Geoinformation for Sustainable Development, Cairo, Egypt, June 14-17'th, pp- 1-6.

Ghabour, TH.K., 1998. Land capability classification of Northern Sinai Governorate using GIS. J. Agric. Sci. Mansoura Univ., 23 (12), 5689-5699.

Hamdi, H., Abdelhafez, S., 2001. Agriculture and soil survey in Egypt. In: Zdru li P. (ed.), Stedu to P. (ed.), Lacirign ola C. (ed.), Mon tan arella L. (ed.). Soil resources of Southern and Eastern Mediterranean countries. Bari: CIHEAM, pp111-125.

Hassan, F.O., 2017. A study on Soil and Water Resources in Halayib and Shalateen area Using Optical and Radar Remote Sensing and GIS Techniques. MSc. Thesis, Fac. Agric. Benha Univ., Egypt.

Ismail, H.A., Bahnassy, M.H., Abd El-Kawy, O.R., 2005. Integrating GIS and modeling for agricultural land suitability evaluation at East Wadi El-Natrun, Egypt. Egypt. J. Soil Sci., 45, 297-322.

Jalhoum, M.E., 2019. Study of agro-ecological zones in some arable land of Egypt using geospatial and hyper-spectral data. PhD. Thesis, Soil and Water Department, Fac. Agric., Suez Canal Univ., Egypt, p- 227.

Mahmoud, E.A., Sayed, A.S.A., Aldabaa, A.A.A., 2019. Land Capability Classification of Wadi Jerafi Basin, North Sinai Egypt. Alex. Sci. Exch. J., 40 (1), 43-59.

Patel, N.R., 2003. Remote sensing and GIS application in agro-ecological zoning. Satellite Remote Sensing and GIS Applications in Agricultural Meteorology, Proceedings of the Training Workshop July 7-11 ${ }^{\text {th }}$ Dehra Dun, India, 213-233.

Salem, M.Z., Ageeb, G.W., Rahim, I.S., 2008. Land suitability for agricultural of certain crops in AlBostan area, Egypt. J. Agric. Biol. Sci. 14 (5), 485499.

Suriadikusumah, A., Herdiansyah, D.G., 2014. Study on Land Resources Based on AgroEcological Zones in Bandung District, West Java - Indonesia. Int. J. Applied Sci. Technol., 4 (4), 212-220.

Soil Survey Manual, 2017. Soil Survey Division Staff. Soil Conservation Service. U. S. Department of Agriculture Handbook 18.

USDA, 2014. Keys to soil taxonomy. $12^{\text {th }}$ Edition. United State Department of Agriculture, Natural Resources Conservation Service (NRCS).

USDA, 2004. Soil Survey Laboratory Methods Manual, Soil Survey Investigation Report No. 42 Version 4.0. 
Table 1. Geomorphology units and soil taxonomy of Sinai Peninsula.

\begin{tabular}{|c|c|c|}
\hline Geomorphology units & Soil taxonomy & Area (acre) \\
\hline Alluvial fans & Vertic Torriorthents & 194713.5 \\
\hline Coastal plains & Typic Hydraquents & 623881.2 \\
\hline Decantation basin & \multirow{2}{*}{ Typic Calciorthids } & 24621.8 \\
\hline \multirow[t]{2}{*}{ Dry Wadis } & & 839719 \\
\hline & Total & 864340.8 \\
\hline Delta & Oolitic Torripsamments & 44928.8 \\
\hline Sabkhas & Typic Hydraquents & 196429.5 \\
\hline Foot slopes & Lithic Calcic Gypsiorthids & 672296.9 \\
\hline High recent river terraces & \multirow{8}{*}{ Typic Torripsamments } & 120895.5 \\
\hline Moderate recent river terraces & & 21717.3 \\
\hline Low recent river terraces & & 72744.4 \\
\hline High sandy sheets & & 105716 \\
\hline Moderate sandy sheets & & 102899.4 \\
\hline Low sandy sheets & & 52172.2 \\
\hline Outwash plain & & 48290.2 \\
\hline \multirow[t]{2}{*}{ Sandy plains } & & 631803 \\
\hline & Total & 1156238 \\
\hline Sand dunes & & 1113614.3 \\
\hline Peniplains & & 422938.9 \\
\hline \multirow[t]{3}{*}{ Rock land } & & 8654707.2 \\
\hline & & 10191260.4 \\
\hline & & 13944089.1 \\
\hline
\end{tabular}

Table2. Land capability in Sinai Peninsula.

\begin{tabular}{lcccccccc}
\hline \multicolumn{7}{c}{ Land capability in Sinai } \\
\hline Classes & C3 & C4 & C5 & C6 & $\begin{array}{c}\text { Peneplain } \\
\text { s }\end{array}$ & $\begin{array}{c}\text { Sand } \\
\text { Dunes }\end{array}$ & $\begin{array}{c}\text { Rock } \\
\text { land }\end{array}$ \\
\hline $\begin{array}{c}\text { Area (acre) } \\
\begin{array}{c}\text { Percentage } \\
(\%)\end{array}\end{array}$ & 300890.4 & 1178509.4 & $\begin{array}{c}1663500 \\
4\end{array}$ & 610710.6 & 422938.9 & 1113614.3 & 8654707.2 \\
\hline
\end{tabular}

Table 3. Agro-ecological zones in Sinai Peninsula.

\begin{tabular}{ccccccc}
\hline \multicolumn{7}{c}{ Agro-ecological zones in Sinai Peninsula } \\
\hline Zones No. & Zone 1 & Zone 2 & Zone 3 & Zone 4 & Zone 5 & Reference Terms \\
\hline Area (acre) & 565999.5 & 8080.7 & 2184353.0 & 997885.1 & 1263769.7 & 8867595.6 \\
Percentage (\%) & 4.1 & 0.1 & 15.7 & 7.2 & 9.1 & 63.9 \\
\hline
\end{tabular}




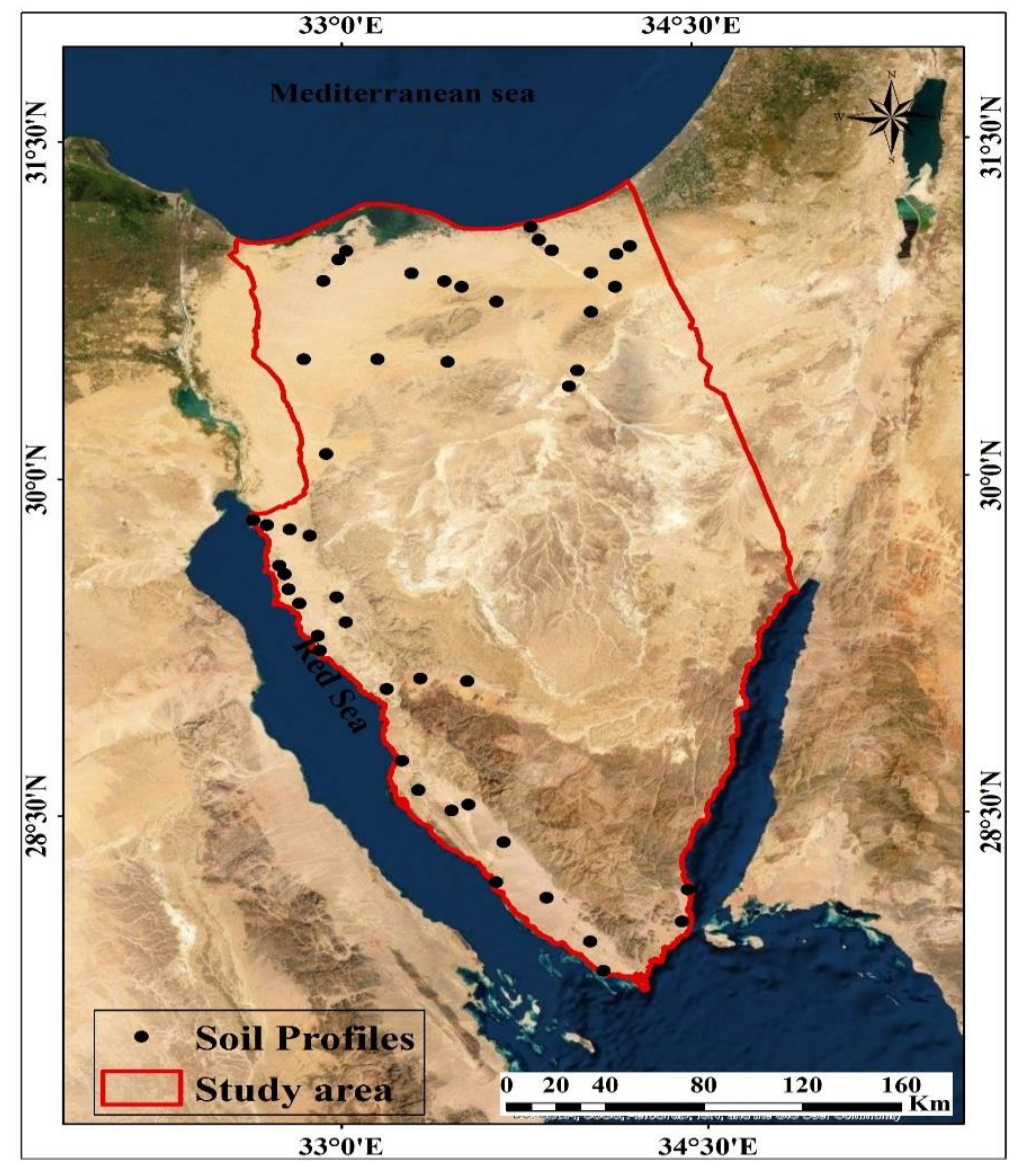

Fig. 1. The location of the study area.

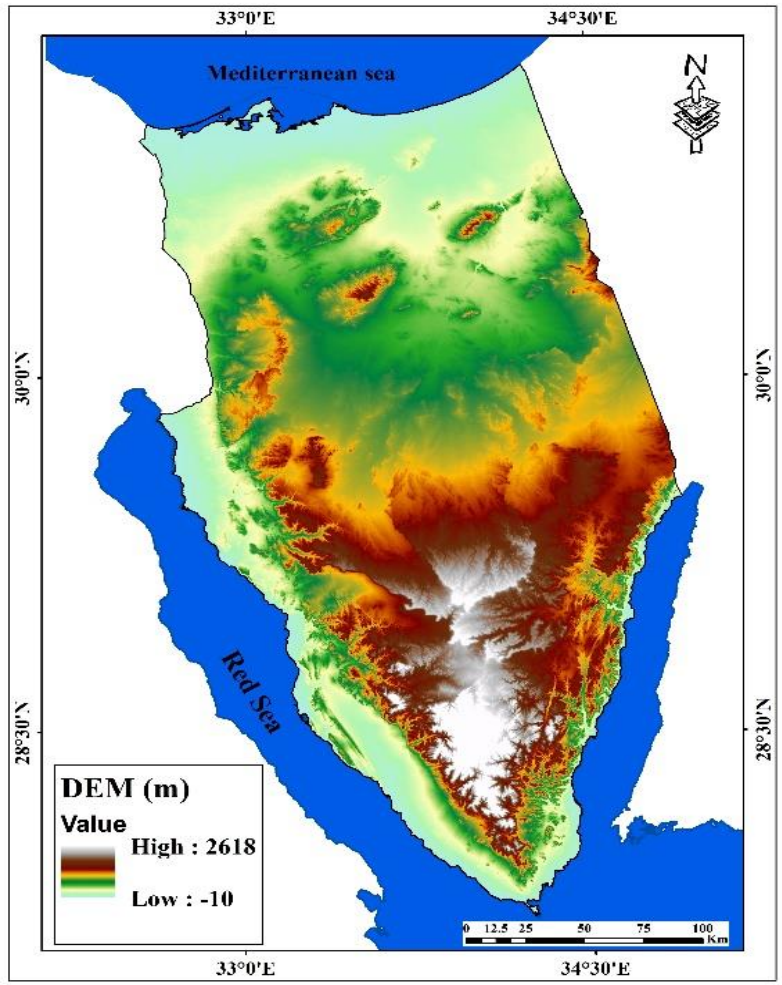

Figure 3. Digital elevation model (DEM) for the study area.

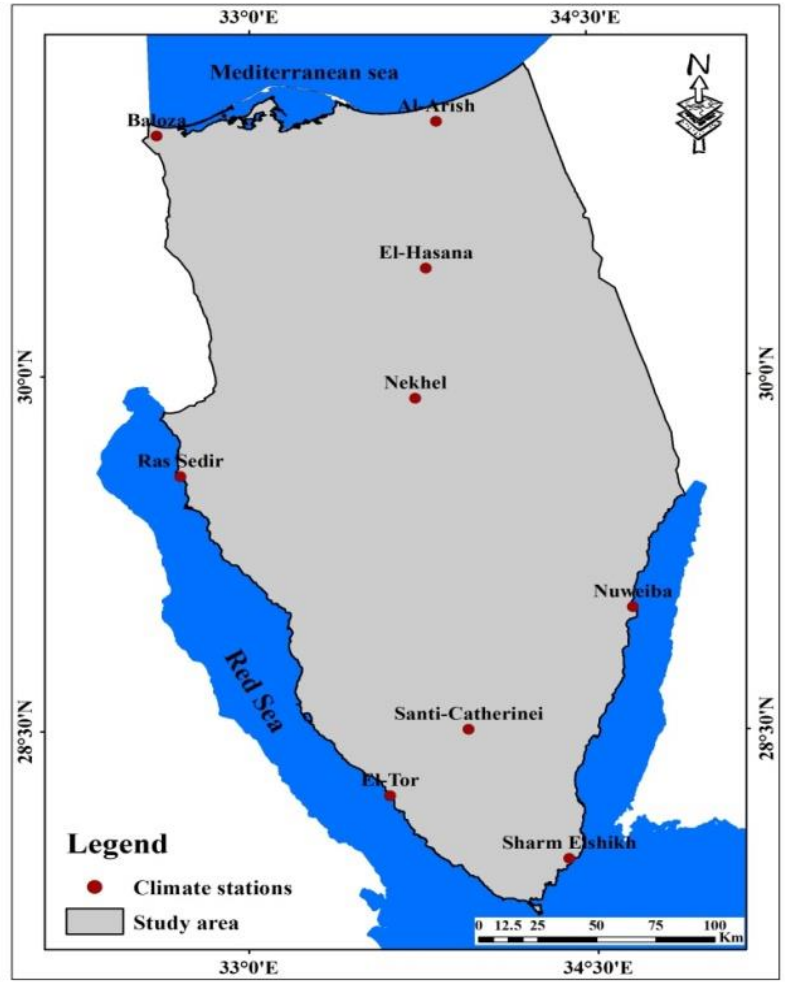

Figure 2. Distribution of ground agro-meteorological stations on the study area. 


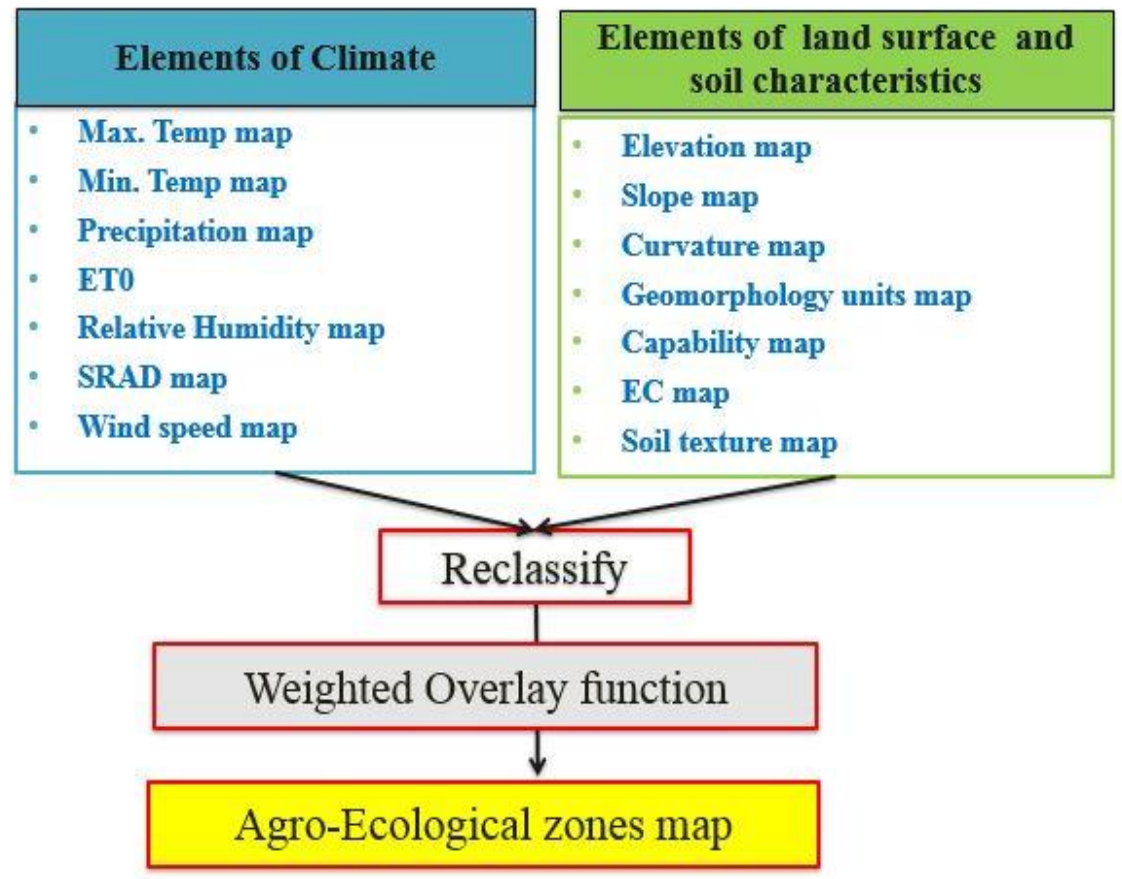

Figure 4. The structure of agro-ecological zones model.
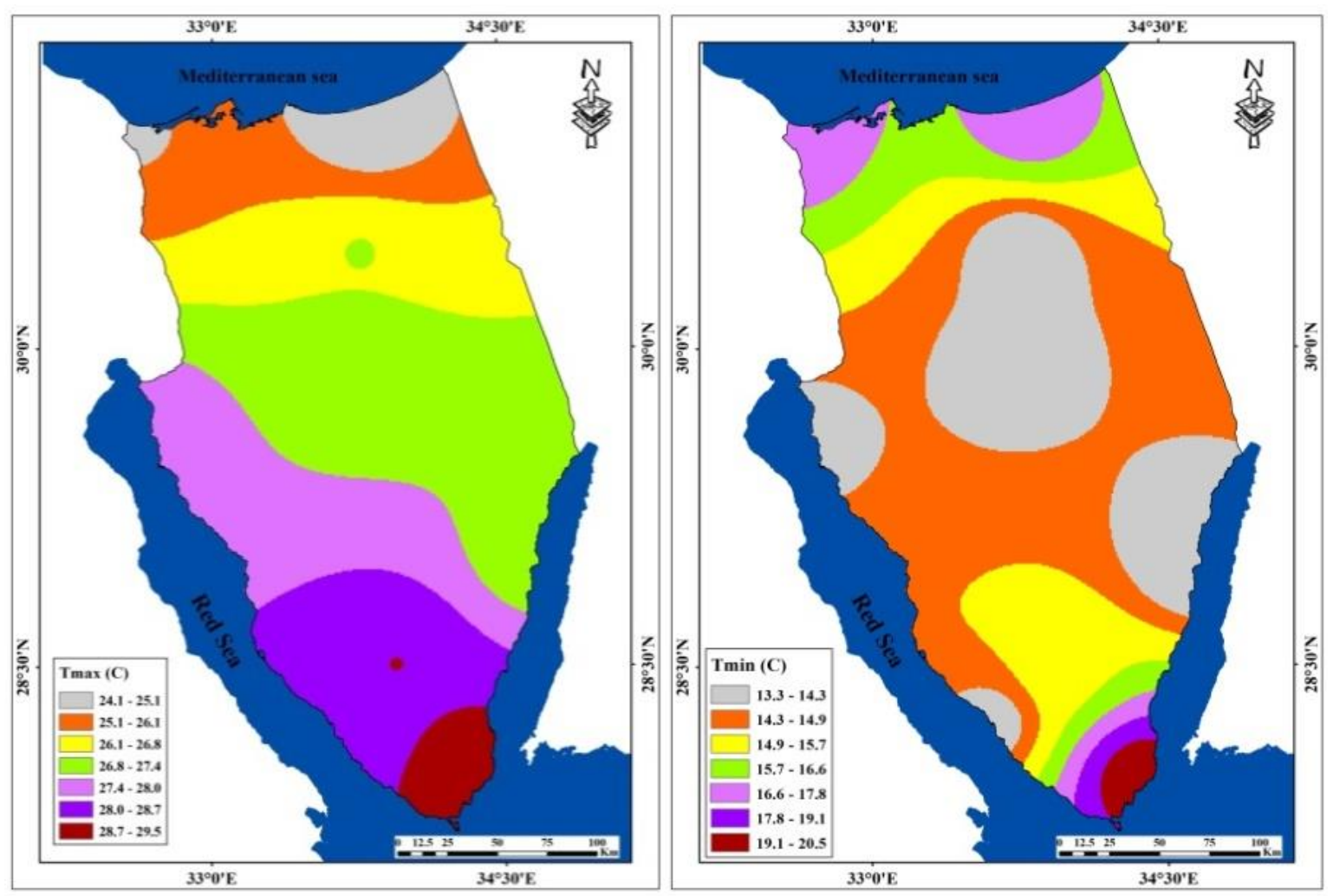

Figure 5. Assessment of max. and min. temperature in Sinai Peninsula. 

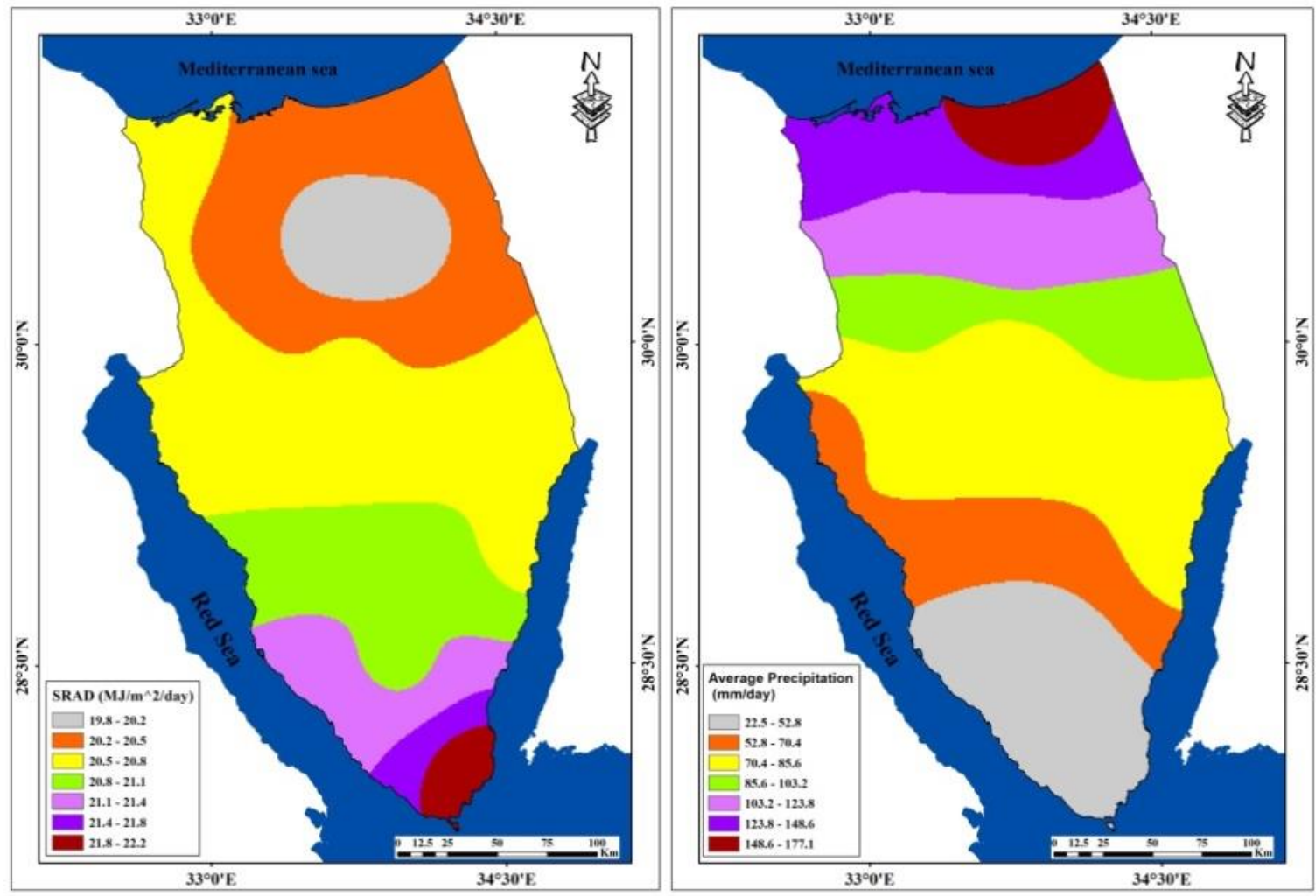

Figure 6. Assessment of radiation and precipitation in Sinai Peninsula.
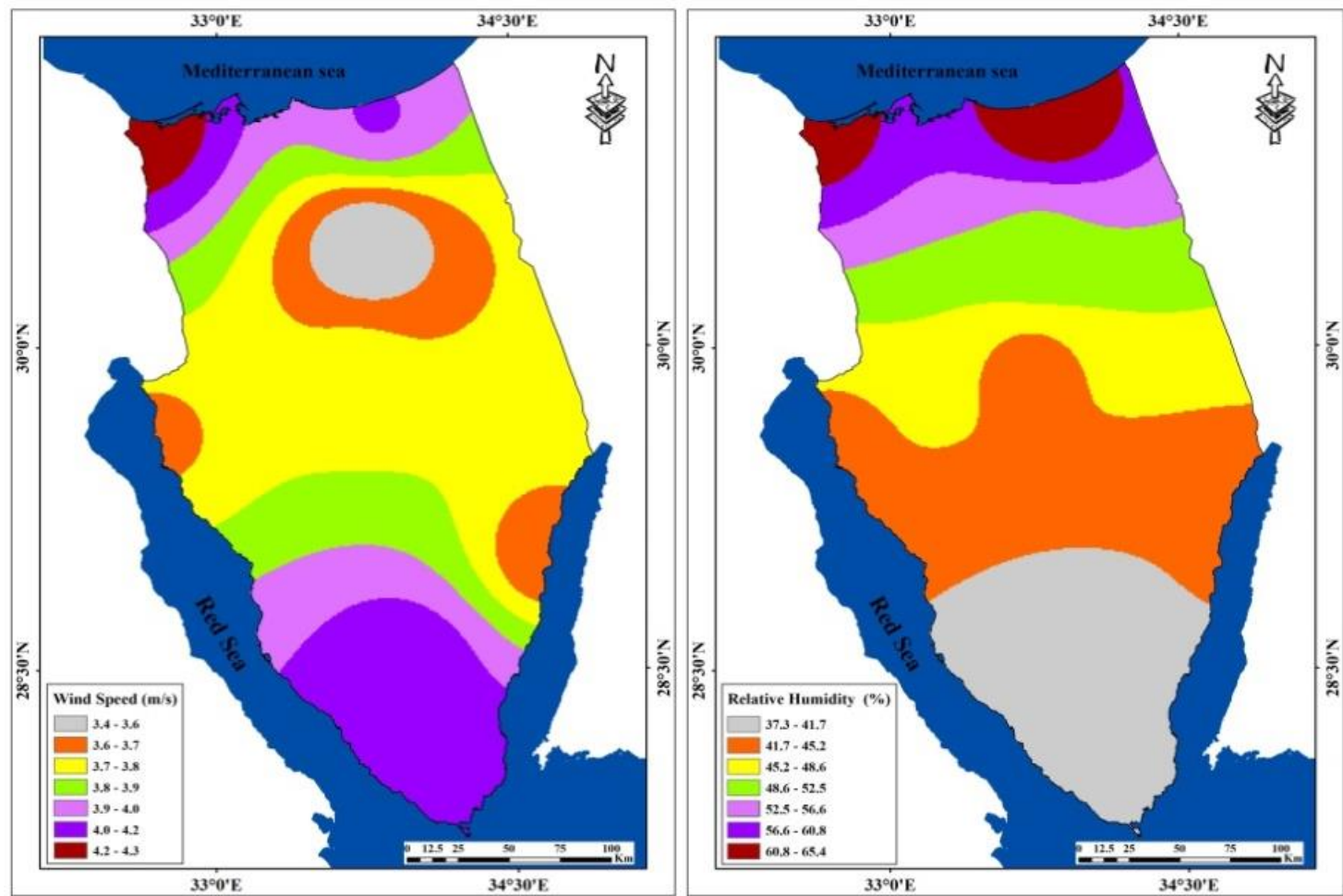

Figure 7. Assessment of wind speed and relative humidity in Sinai Peninsula. 


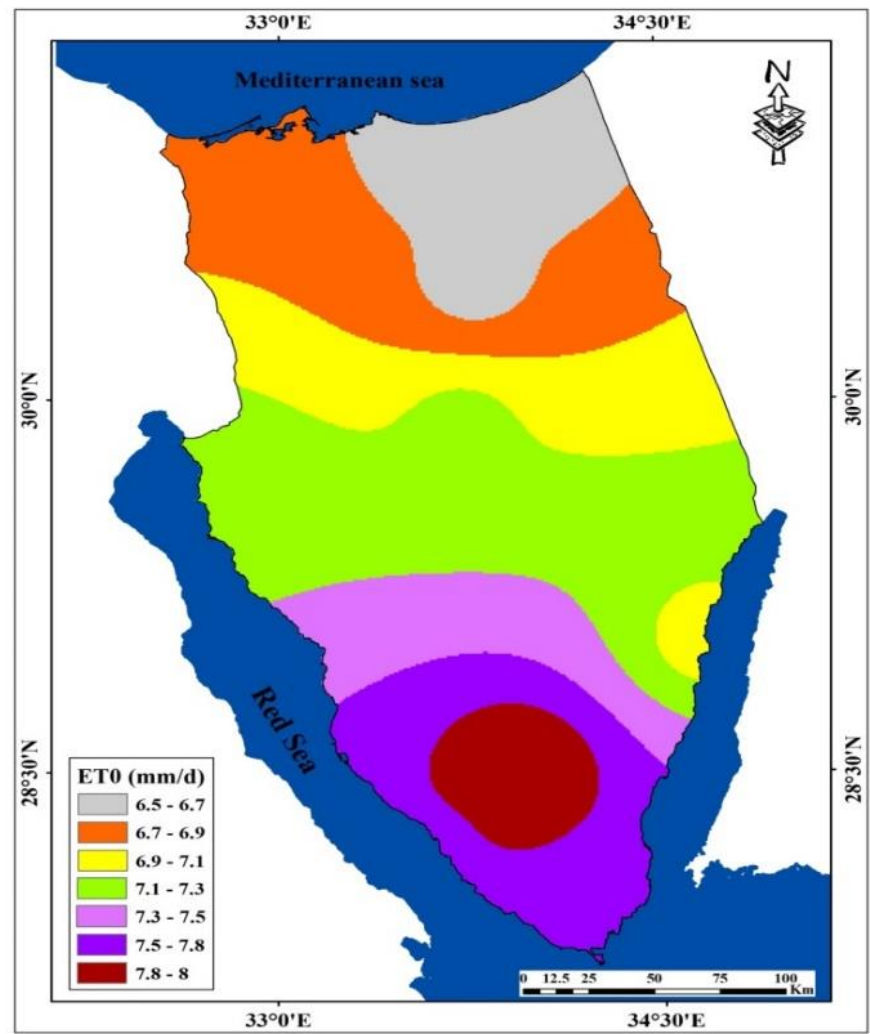

Figure 8. Assessment of evapotranspiration $\left(\mathrm{ET}_{0}\right)$ in Sinai Peninsula.

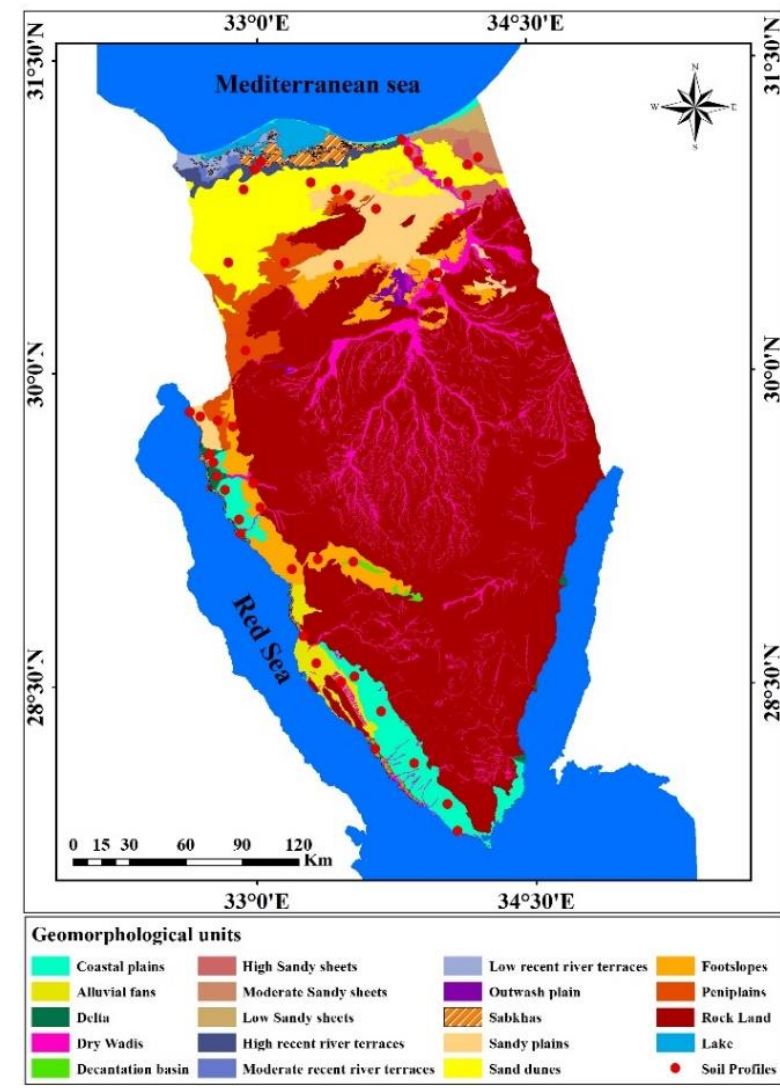

Figure 9. Geomorphology units of Sinai Peninsula.

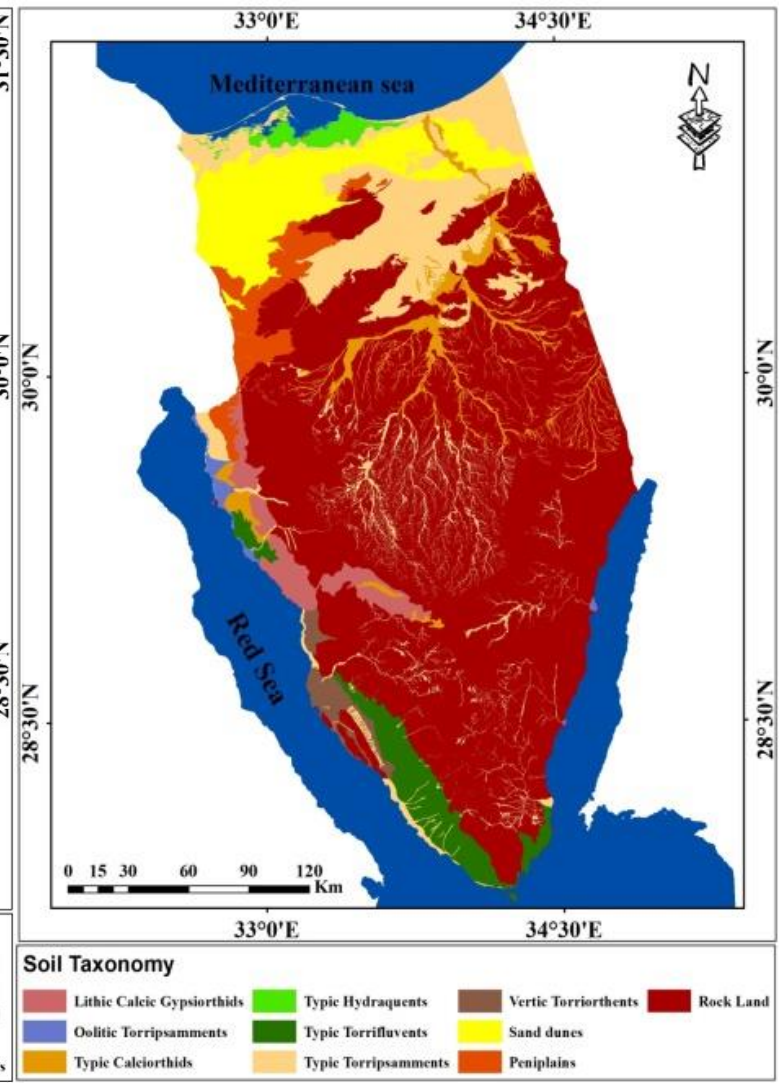

Figure 10. Soil taxonomy in Sinai Peninsula. 


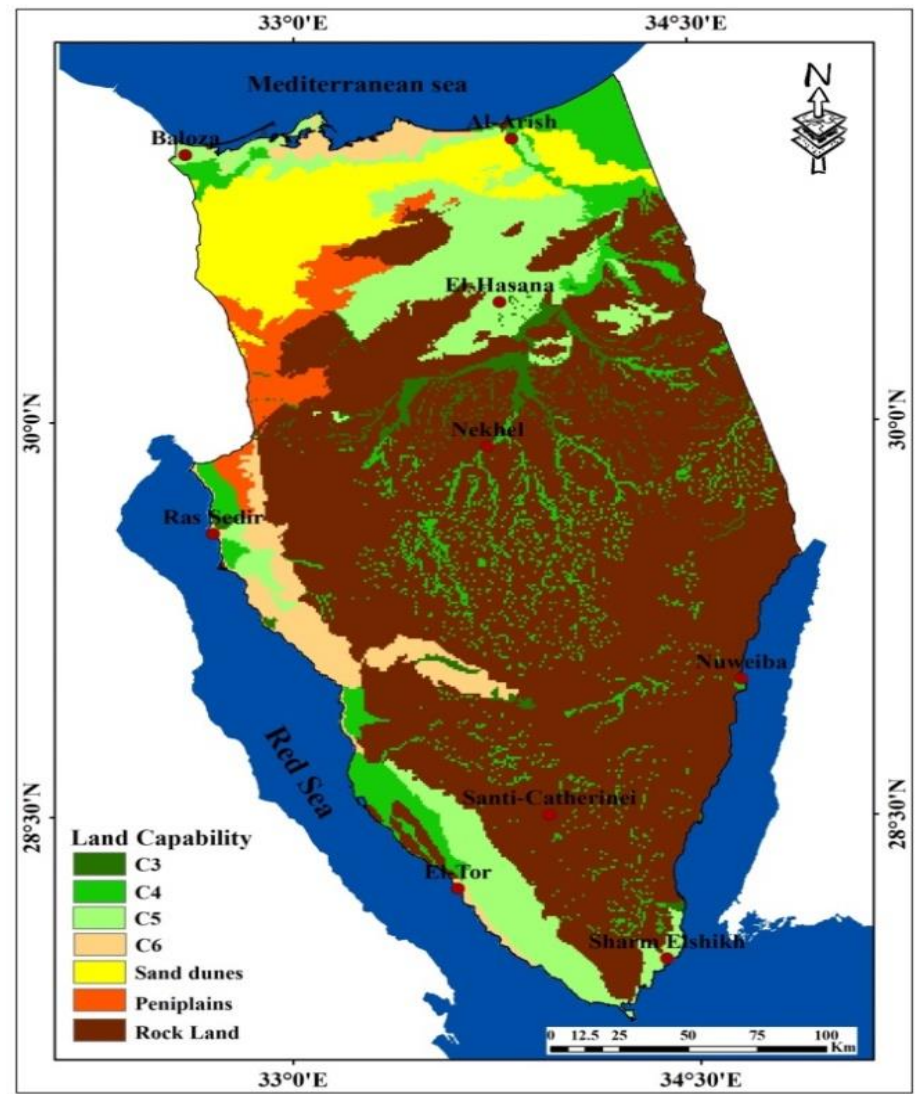

Figure 11. Land capability in Sinai Peninsula.

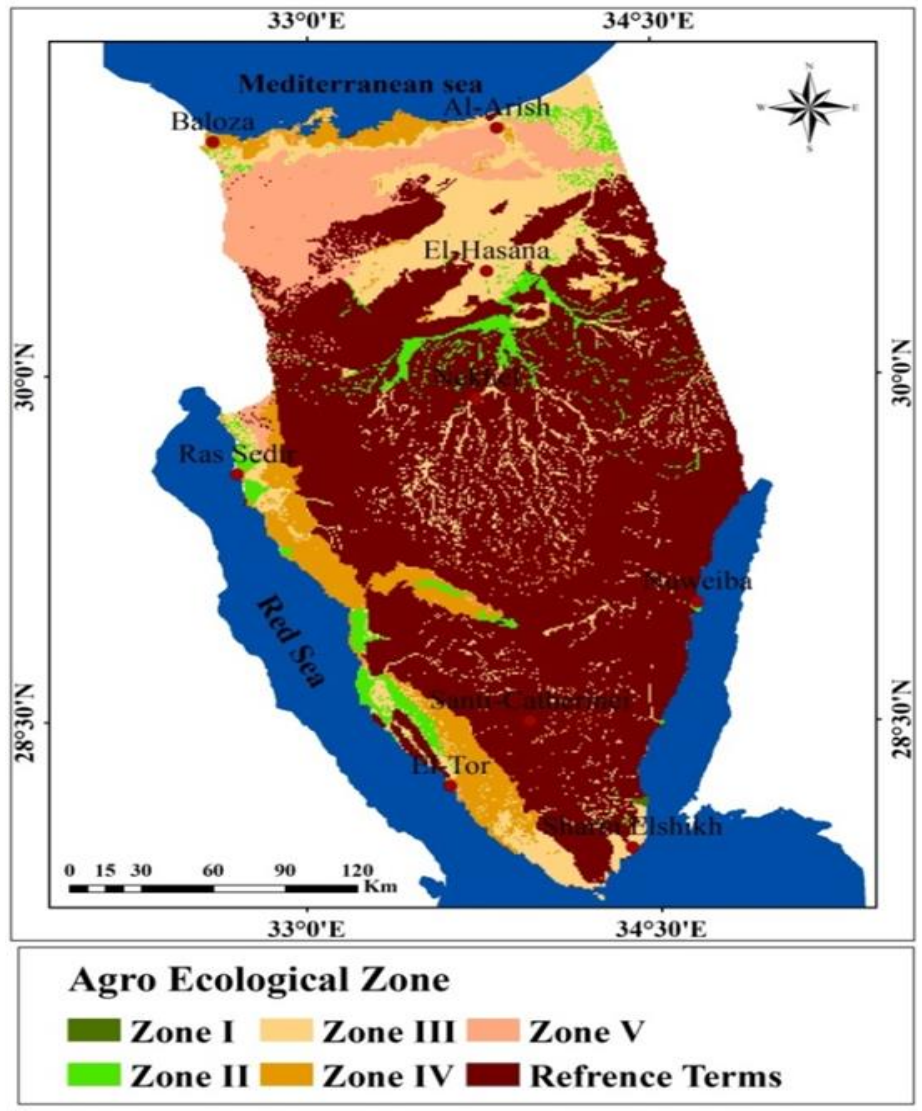

Figure 12. Agro-ecological zones in Sinai Peninsula. 


\section{تحديد النطاقات الزراعية كاساس للثنية الزراعية في شبه جزيرة سيناء باستخدام تثنيات المعلوماتية الجغرافية}

$$
\begin{aligned}
& \text { سمير مسعود ابوشليل "،"، محمد السيد جلهوم ؟، عبد العزيز بلال r }
\end{aligned}
$$

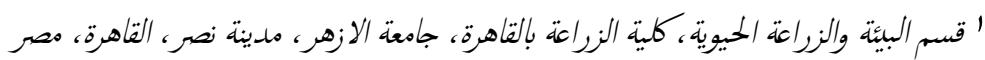

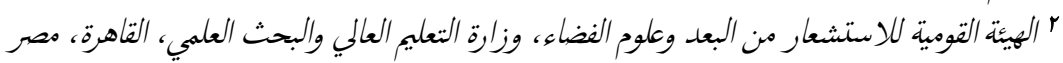

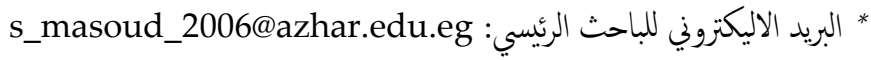

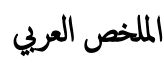

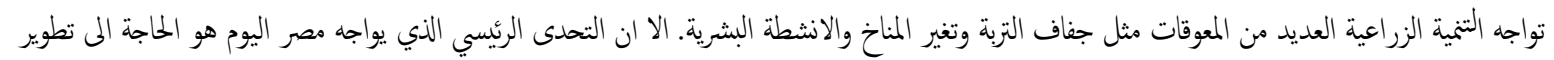

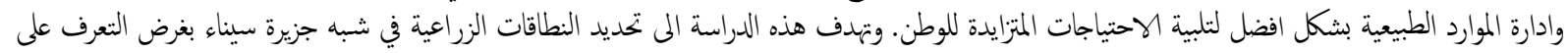

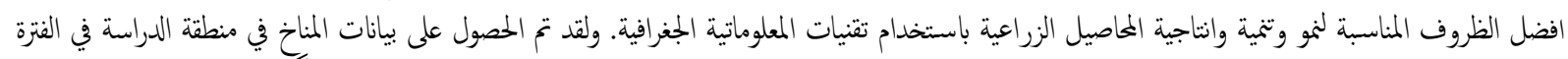

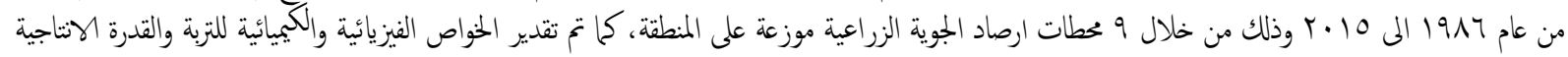

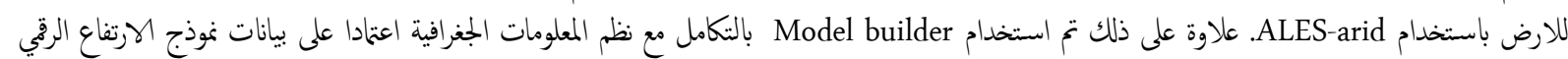
(DEM)

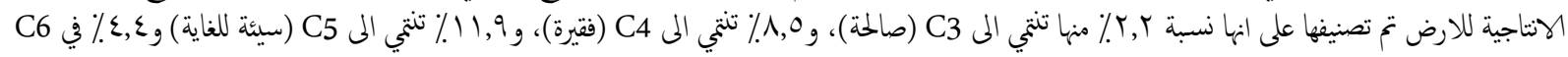

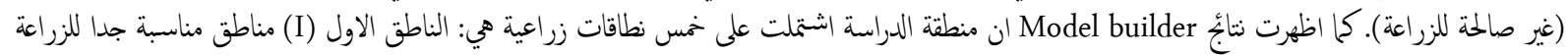

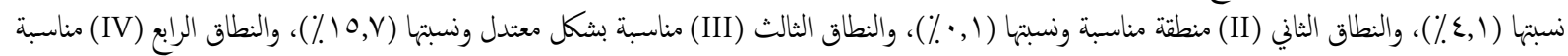

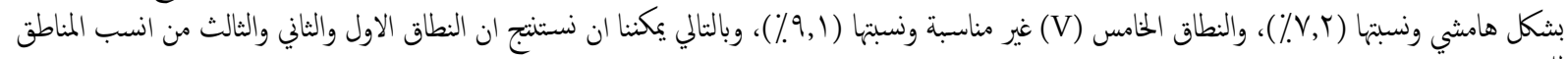
للنمية الزراعية في شبه جزيرة سيناء. الكلمات المفتاحية: النطاقات الزراعية، المعلوماتية الجغرافية، جيومورفولوجي، القدرة الانتاجية للارض، شبه جزيهرة سيناء. 